\title{
A Note On The Adoption Of The Euro Compared To The Adoption Of "Federal Money" In The United States
}

George E. Nogler, University of Massachusetts, Lowell

John A. Armstrong, (Email: john.armstrong@nichols.edu), Nichols College

\begin{abstract}
This paper compares and contrasts the experience of the European Community in creating a single monetary unit (the Euro) from the currencies of a dozen participating member states to the experience of the United States in creating a single monetary unit (the dollar) across the former colonies after the American Revolution. The European Community was able to merge the member state currencies in a period of 23 years, while the United States experience lasted over 75 years. By extensively reviewing the experience of the United States through contemporaneous textbooks, two factors are identified which may account for this difference. First, the existence of a central bank, and second, the universal adoption of decimal currencies, which began with the United States experience.
\end{abstract}

\section{INTRODUCTION}

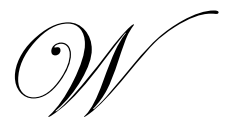

hen the former British colonies became the United States following the American Revolution, they faced a task similar to that of the European Community's recent efforts to establish a single currency. The thirteen original states had four independent regional currencies. This circumstance added complexity to commerce between the states.

The experience of the European Community in creating a single monetary unit (the euro") out off a bewildering maze of national currencies (e.g., lira, franc, deutsche mark, peseta, etc.), for all its confusion, took place in substantial shorter time span than did the integration of regional colonial currencies into the United States dollar.

The European Community began the process on March 13, 1979 and effectively converted the currencies of 12 nations into a single currency, the euro, in 2002 (European Union, 2002). This transition was accomplished in a span of 23 years.

Timeline of the establishment of the Euro

\begin{tabular}{|c|c|c|c|c|}
\hline 1979 & 1994 & 1999 & 1999-2002 & 2002 \\
\hline $\begin{array}{l}\text { European Monetary } \\
\text { System is established } \\
\text { March 13, with the } \\
\text { concept of establishing } \\
\text { a common currency } \\
\text { for European } \\
\text { Community members }\end{array}$ & $\begin{array}{l}\text { European Monetary } \\
\text { Institute is established } \\
\text { January } 1 \text {, as a } \\
\text { predecessor of a } \\
\text { central bank. }\end{array}$ & $\begin{array}{l}\text { European Monetary } \\
\text { Institute is dissolved } \\
\text { into the European } \\
\text { Central Bank on } \\
\text { January } 1 .\end{array}$ & $\begin{array}{l}\text { Euro is officially } \\
\text { launched. Transition } \\
\text { period for individual } \\
\text { national currencies to } \\
\text { convert to the Euro. }\end{array}$ & $\begin{array}{l}\text { January } 1 \text {, the Euro } \\
\text { enters into circulation. } \\
\text { February } 28, \text { the } \\
\text { transition period ends } \\
\text { and the Euro becomes } \\
\text { the sole currency of } \\
\text { the } 12 \text { participating } \\
\text { nations }{ }^{1} \text {. }\end{array}$ \\
\hline
\end{tabular}

${ }^{1}$ The twelve participating Member States at that date were: Austria, Belgium, Finland, France, Germany, Greece, Ireland, Italy, Luxembourg, the Netherlands, Portugal and Spain. 
An analogous situation existed within the United States from the inception of a Federal Monetary system for the United States in 1786 and the creation of the U. S. Treasury Department, under Alexander Hamilton, in 1791 through the Civil War, a period of over 75 years before the United States had a single unified currency (U.S. Treasury Department 2005, Federal Reserve Bank of San Francisco 1995).

Timeline of the establishment of the Dollar

\begin{tabular}{|c|c|c|c|c|}
\hline 1785 - 1786 & 1791 - 1811 & 1816 - 1836 & $1836-1863$ & $1863-1864$ \\
\hline $\begin{array}{l}\text { July } 6,1785 \text {, } \\
\text { Continental Congress } \\
\text { establishes the "dollar" } \\
\text { as the monetary unit of } \\
\text { the United States. } \\
\text { September 1786, the } \\
\text { Annapolis Convention } \\
\text { creates the Department } \\
\text { of the Treasury. }\end{array}$ & $\begin{array}{l}\text { February } 25, \text { At the } \\
\text { insistence of the first } \\
\text { Treasury Secretary, } \\
\text { Alexander Hamilton, } \\
\text { the First Bank of the } \\
\text { United States becomes } \\
\text { the first central bank, } \\
\text { its charter expired on } \\
\text { March } 4,1811 \text {. }\end{array}$ & $\begin{array}{l}\text { April 10, Second Bank } \\
\text { of the United States } \\
\text { chartered as a central } \\
\text { bank with } 25 \\
\text { branches. Renewal is } \\
\text { vetoed by Andrew } \\
\text { Jackson in } 1832 \text { and } \\
\text { bank ceases to } \\
\text { function in } 1836 \text {. }\end{array}$ & $\begin{array}{l}\text { State-chartered and } \\
\text { un-chartered banks } \\
\text { provide own } \\
\text { banknotes as currency. }\end{array}$ & $\begin{array}{l}\text { National Currency Act } \\
\text { on Feb. } 25,1863, \\
\text { establishes the } \\
\text { "greenback." National } \\
\text { Bank Act on June 3, } \\
1864 \text { provides for } \\
\text { centralized nationally } \\
\text { chartered banks. }\end{array}$ \\
\hline
\end{tabular}

At various points in this juncture, along with "Federal Money," denominated in dollars and cents (the dollar was adopted by the Continental Congress as the unit of exchange in 1786), there also existed regional currencies denominated in the English style of pounds, shillings, pence, and farthings, at least through the 1820s. This was followed by a proliferation of regional banks, issuing "bank notes" after President Andrew Jackson vetoed the Bank Act, which would have continued the central bank beyond 1836 .

\section{HISTORY OF CURRENCY EXCHANGES INVOLVING FEDERAL MONEY}

The existence of four distinct regional currencies led to the need to convert currencies from one region of the country to another and from regional currencies to the new Federal money (dollars). In 1788, Nicolas Pike, A.M. published A New and Complete System of Arithmetic Composed for the use of the Citizens of the United States. In this extensive (512 page) text, Pike reprints the Act of Congress of 1786 that created the Federal Money system. However, he does not provide rules for dealing in regional currency conversion to Federal Money (Nietz, 1961). This book was followed by Benjamin Workman's American Accountant, or Schoolmaster's New Assistant in 1793. Chauncey Lee's American Accomptant, for the bookkeeper followed in 1797 which is perhaps best noted as the first to use the dollar (\$) symbol to denote federal money. In 1801, Daniel Adams published what is arguably one of the most accessible texts to describe the monetary conversion process in the United States entitled The Scholar's Arithmetic: or, Federal Accountant. This book, with various revisions and editions, remained in print into the 1860s (Nietz).

Since Adams' book is one of the first and certainly one of the most accessible and influential, the $1816\left(10^{\text {th }}\right)$ edition of his book will be used to illustrate the issues here. In the Preface to this edition, Adams specifically notes that he has expanded his coverage of currency exchange.

But what more particularly claims attention in this revised edition, is the introduction of the rule of Exchange, where the pupil is made acquainted with the different currencies of the several states, (that of South Carolina and Georgia, only excepted,) and how to change these currencies from one to another; also to Federal Money, and Federal Money to these several currencies. This has been done more particularly with a view to the accommodation of the State of New York, and other more southern states, where this work has already acquired very considerable circulation. (p.iii).

Federal money was denominated as eagles (\$10), dollars, dimes, cents, and mills (even at this point the mill is referred to as "imaginary coin" (Adams, p. 80). A mill was originally an English and Scottish monetary unit that was equal to 13 shillings and 4 pence (American Heritage Dictionary, 2000) but in dollar coinage became equal to $1 / 10$ of a cent of $1 / 1,000$ of a dollar. Certain states still use the mill for certain tax assessment purposes ${ }^{[1]}$. The 1792 
US Coinage Act defined the dollar: "the Dollar or Unit shall be of the value of a Spanish milled dollar as the same is now current, to wit, three hundred and seventy-one and one-quarter grains of silver."

The states had long used their own or regional currencies, however, an Act of Congress in 1786 established "Federal Money" as the official currency of the United States. This circumstance gave rise to the necessity to provide guidance in the exchange of the various regional currencies among themselves as well as to and from federal money.

By 1816, the publication of this book, the United States was comprised of seventeen states. The currencies of the New England States, Ohio and Virginia are referred to as "New England Currency." This currency was prevalent in eight states: Connecticut, Kentucky (originally part of Virginia), Massachusetts, New Hampshire, Ohio, Rhode Island, Vermont, and Virginia. The sixth New England state, Maine, was part of Massachusetts and did not become a distinct state until 1820. The currency of New York and North Carolina, was the same and was prevalent in those two states. This currency is referred to as "New York Currency." The currencies of New Jersey, Pennsylvania, Delaware, and Maryland, referred to as "Pennsylvania Currency" was prevalent in those states. South Carolina and Georgia also had their own currency in this period. Adams' text does not address conversion of this last currency. Interestingly, Adams' introduction notes that in providing rules for exchange "that of South Carolina and Georgia only [are] excepted," however, he does not mention the seventeenth state - Tennessee - in the text. Tennessee, in fact, was originally a territory of North Carolina, so it seems likely that this would be the dominant currency. These four currencies existed concurrent with "federal money" well into the 1820 s.

\section{FEDERAL MONEY}

Computations involving receipts, payment, or division of Federal Money in 1816 would be straightforward today with the addition that mills (the "imaginary coin") are computed in divisions of cash and eliminated in rounding. For example, "A man dies, leaving an estate of $\$ 71600$, there are demands against the estate of $\$ 39876,74$; the residue is to be divided between 7 sons; what will each one receive?" "Ans. $\$ 4531$ 89cts" (\$4,531.89). (Adams, p. 83)

The answer here is obtained, as currently, by subtracting the demands from the estate to determine the distributable amount and then simply dividing that number by 7 . Or, $\$ 71,600$ less $\$ 39,876.74$ equals $\$ 31,723.26$ divided by 7 equals $\$ 4,531.89$.

Some interesting aspects of the evolution of financial reporting and social norms may also be observed here. Commas are not used to separate thousands as currently. The English method of using commas rather than decimal points was still generally the style in 1816 . To illustrate, the amount $\$ 4,531.89$ (commonly understood as four thousand five hundred thirty one dollars and eighty nine cents) is written as $\$ 453189 \mathrm{cts}$. It is noted however "Accountants generally omit the comma and distinguish cents from dollars by setting them apart from the dollars.(Adams, p. 81)" In other words $\$ 4,531.89$ would be presented as $\$ 453189$. When the use of the decimal in monetary shorthand became common practice is not clear. Additionally, the example comprehends the residue to be divided among "sons" without mention of daughters.

\section{EXCHANGING REGIONAL CURRENCIES TO AND FROM FEDERAL MONEY}

The author, Daniel Adams, admonishes "the Scholar" in the Introduction:

Be not in a hurry to get through your book too soon. Much instruction may be given in these few words, UNDERSTAND EVERY THING AS YOU GO ALONG . . Each rule is first to be committed to memory: afterwards, the examples in illustration, and every remark is to perused with care. There is not a word inserted in this Treatise, but with a design that it should be studied by the Scholar. (Adams, p. 7, emphasis in the original.)

It should be noted that this book is contemporaneous with a period when what today would be called professionals often studied without the benefit of colleges and universities. Lincoln, for example, was a self-taught lawyer, being licensed in 1836 by passing a bar exam after self study - "reading the law." For law, this method is 
currently allowed in only seven states: Vermont, New York, Washington, Virginia, California, Maine, and Wyoming. Accountants, likewise were not licensed by the states so could be self taught and then simply hold themselves out to be accountants. The first accounting association was established in Edinburgh, Scotland in 1854. The first professional society of accountants in the United States was the American Association of Public Accountants chartered in New York in 1887 (Encyclopedia.com, 2002). It was not until 1884 that the Institute of Accounts began issuing certificates of competency to accountants. Accountants were not licensed in the United States until 1896 (Flesher et al, 1996). Until that point, success in the accounting profession, then, depended on ability and reputation without the credential of a license or even, necessarily, a degree.

Greater difficulties arise when exchange between regional currencies and Federal Money occurs. Adams defines exchange as "the giving of bills, money, weight, or measure of one place or country, for the like value in bills, money, weight or measure of another place or country." The wisdom of the author's caution that every word is inserted with great care - and one might add with great economy - is evident in the instruction below. Here for example is the rule to convert New England Currency or New York Currency to Federal Money.

Set down the number of pounds and to the right hand write half the greatest even number of the given shillings: then consider how many farthings there are contained in the given pence and farthings, if the sum exceed 12, increase it by 1 , or if it exceed 36, increase it by 2, which sum is set down to the right hand of half the greatest even number of shillings before written, remembering to increase the second place, or the place next to the shillings by 5, if the shillings be an odd number; to the whole sum thus produced, annex a cipher, and divide by 3 , if it be N. England currency, ... ; cut off the three right hand figures in the quotient, which will be cents and mills; the rest will be dollars. (Adams, p. 84).

Adams Then Proceeds To Solve For Exchanging 47 New England Pounds, 7 Shillings, And 10 3\%4 Pence (£47 7 s. 10 3/4 D.) To Federal Dollars As Follows (Adams, $P$ 84):

\begin{tabular}{|l|l|l|l|l|}
\hline $\begin{array}{l}\text { The } \\
\text { pounds }\end{array}$ & $\begin{array}{l}\text { Half the } \\
\text { even } \\
\text { number of } \\
\text { shillings } \\
\text { farthings in } \\
\text { farthings } \\
\text { increased } \\
\text { according } \\
\text { to rule }\end{array}$ & $\begin{array}{l}\text { Cypher } \\
\text { annexed. }\end{array}$ & $\begin{array}{l}\text { In this example to the right hand of pounds (47) I write 3, half } \\
\text { the greatest even number of the given shilling (7); the farthings } \\
\text { in } 10 \text { s/4 (43) increased by two (45) because exceeding 36 } \\
\text { and the second place increased by 5 because the shillings were } \\
\text { an odd number, make 95, which sum written to the right hand if } \\
\text { the 3, a cipher annexed, and the sum divided by 3 gives the } \\
\text { answer 157 dollars, 98 cents, and 3 mills for } N . \text { England } \\
\text { currency. }\end{array}$ \\
\hline 47 & 3 & 95 & 0 & Divide by 3 \\
\hline 157,983 & & Dolls. \\
\hline
\end{tabular}

The difficulty that arises in converting New England currency as described above into Federal money comes largely from the lack of a consistent decimal relationship between the coins. A farthing, used here as a sort of lowest common denominator is equal to $1 / 4$ of a pence. A shilling ("s.") is equal to 12 pence ("d."). A pound ("£”) is equal to 20 shillings (Adams notes at the bottom of the page, however, "A little practice will make these operations extremely easy.

Simplified, using the methods we use today, the conversion rate (which can be derived) is $£ 1$ (New England) pound is worth $\$ 3.33$ 1/3 Federal dollars, or one Federal dollar ( $\$ 1$ ) equals $£ .30$ (New England pounds). If we use current parlance here and describe federal dollars as the local currency and New England pounds as the foreign currency, the direct exchange rate becomes $\$ 3.331 / 3$ and the indirect exchange rate is $£ .30$.

Dividing the pounds by 3 and effectively moving the decimal one place to the right (1/3), as is done by Adams, is the same as dividing the pounds by the indirect exchange rate of $£ .30$. Alternatively, multiplying the pounds by direct exchange rate of $\$ 3.331 / 3$ yields the same result. Therefore we need to convert shillings and pence to decimals of pounds. So we can start with 47 pounds, then compute the decimal of shillings to pounds simply by dividing the shillings by 20 , or $7 / 20=.35$, then convert the pence to shillings then pounds or $10.75 / 12=.8958$ 
shillings divided by $20=.0448$ pounds (or directly by dividing the pence by 240). Adding pounds (47), shillings (.35) and pence (.0448), now all denominated in decimal format, we get 47.3948 multiply by $\$ 3.331 / 3$ (pound to dollar conversion rate) $=\$ 157.98$, with a rounding of .003 , or technically, 3 mills, the same answer derived in The Scholar's Arithmetic.

Adams also provides the rules for conversion from New York currency and Pennsylvania currency. The conversion for New York currency is the same as New England except that the division is by 4, rather than 3. The implied direct exchange rate is $\$ 2.50$ per $£ 1$ (New York pound) and the indirect rate is $£ .40$. Either multiplying by the direct rate or dividing by the indirect rate yields the answer in the above exercise of $\$ 118.48$, with 7 mills. This is the same answer provided by Adams.

The conversion proposed by Adams for Pennsylvania currency is illustrated with an entirely different numerical problem. He proposes exchanging $£ 17$ 1s. $6^{1 / 2}$ p. to Federal money. Using the rules above, we can obtain the decimal equivalent in pounds as $£ 17.077$. The direct exchange rate implied by Adams computation ("multiply by 8 and divide by 3") is $\$ 2.662 / 3$ dollars per (Pennsylvania) pound, and the indirect rate $£ 0.375$. Either multiplying by the direct rate or dividing by the indirect rate yields the answer in the above exercise of $\$ 45.53$, with 8 mills. This is the same answer provided by Adams. (p. 87).

Why Adams does not suggest this more direct method is problematical. This book, The Scholar's Arithmetic, or the Federal Accountant, was the most widely used text of its day, in circulation in various editions from 1801 until the 1860s, according to Nietz (1961). There are three possible reasons why Adams suggested such a clearly obtuse method.

- $\quad$ First, this method appears to have been the traditional ("generally accepted") method of the day. Adams states in his Preface "such rules and remarks as have been compiled from other authors are included in quotations; the Examples, many of them are extracted; this I have not hesitated to do, when I found them suited to my purpose." This statement in itself places Adams in an odd position as it relates to the ethical aspects of plagiarism, and even the legal aspects of copyright infringement. A version of Pike's System of arithmetick abridged (1826), appearing some ten years after the edition of Adams cited here, provides a chapter on the "Reduction of Other Currencies to Federal Money, \&c." which offers a rule very similar to Adams.

- $\quad$ Second, the complexity may have been somewhat intentional to provide a barrier of entry to the profession of accountancy. As noted, this book circulated at a time when many professionals were self-taught. The author of 1792 book published in London describes the author as "George Fisher, accomptant.(Fisher, 1792)" The use of the term suggests that the individual was practicing as an accountant, but the title is self-granted, as licensing procedures were not yet in place. The tone of Adams Preface and his Directions to the Scholar suggest that the book can be used as a self study guide, although the Recommendations make it clear that it was also used as a textbook, with several academies and Dartmouth College (Adams' alma mater) cited. The complexity of the rule, however, would appear to dissuade all but the brightest or most intrepid "scholars" from holding themselves out as accountants.

- $\quad$ Third, the more direct method suggested here may not have occurred to Adams. Interestingly, Adams was a Medical Doctor, receiving his degree from Dartmouth College in 1797, and a noted mathematician. "Exchange" is defined and described as presented here in The Scholar's Arithmetic as Section II. 4. Section II. 2. relates to decimal operations which provides a basis for computations concerning Federal Money (Section II. 3.). The United States Metric Association credits the United States with pioneering decimal coinage with the introduction of the dollar in 1786 (2005). Clearly, Adams was familiar with decimal manipulations. However, since it appears the more complex rule was the generally accepted method (see above), and the dollar was the first decimal currency, it may not have occurred to Adams to convert the pound currencies to decimal equivalents.

Converting Federal Money (dollars) to a regional currency poses a different problem. This involves converting a decimal currency into the non-decimal regional currency. Again, Adams rule seems unnecessarily complex. 


\section{RULE}

If there be no mills in the given sum, reduce it to mills by annexing ciphers; multiply the given sum by 3 , if it be required to change it to N. E. currency; cut off the four right hand figures, which will be decimals of a pound, the left hand figures will be the pounds. To find the value of the decimals, double the first figure for shillings, and if the figure in the second place be 5, add another shilling, then call the figures in the second and third places, after deducting the 5 in the second place, so many farthings, abating 1 when they are above 12 , and 2, when they are above 36." (Adams, p. 85).

The example, however, is somewhat more direct:

Change 255 Dollars, 40 Cents, And 6 Mills To Pounds, Shillings, Pence, And Farthings.

\begin{tabular}{|c|c|}
\hline Operation & \multirow{5}{*}{$\begin{array}{l}\text { Having multiplied and cut off the four right hand figures as the rule directs, to find the value of the } \\
\text { figures cut off, I double the first figure (6) N. E. Cur. Which gives } 12 \text { shillings: the figures in the } \\
\text { second and third places (21) abating } 1 \text { for being over twelve (20) are considered to be so many } \\
\text { farthings, which reduced to pence are } 5 \ldots \text { The } 8 \text { in the fourth place, being somewhat less than a } \\
\text { farthing, is lost, not being reckoned." (Adams, p. 86). }\end{array}$} \\
\hline 255406 & \\
\hline 3 & \\
\hline $761 / 26218$ & \\
\hline $\begin{array}{l}\text { Ans. £76 12s. 5d. } \\
\text { N. E. cur. }\end{array}$ & \\
\hline
\end{tabular}

In this case, the modern solution is not as direct, but follows the reversal of the prior rule. We would first multiply the amount in dollars by the direct exchange rate of .3, yielding (as above) 76.6218. This gives us 76 pounds. We can then take the decimal remainder (.6218 pounds) and multiply by 20 (the number of shillings in a pound) or .6218 times 20 equals 12.436. So we now have 76 pounds, 12 shillings, and a decimal remainder of .436 expressed now in shillings. This decimal remainder can then be multiplied by 12 (the number of pence in a shilling) to obtain 5.232. This obtains the result $£ 76$ 12s. 5 d. (76 pounds, 12 shillings, 5 pence), with a decimal remainder of .232 pence, which is ignored. Arguably, this method is simplifies Adams' rule, but perhaps not as much as the previous conversion.

This rounding leads to an interesting observation. We could multiply this remainder (.232 pence) by 4 (the number of farthings in a pence) to obtain .928 , or almost one farthing. The rule applied by Adams for rounding, which must have followed the convention of the time, is that any amount less than a whole is rounded down. Note that Adams indicates that the remainder is "lost" as it is "somewhat less than a farthing," even though it is significantly greater $(0.928)$ than our current rounding convention of being greater than half $(0.5)$.

Having presented these somewhat convoluted rules for exchange, Adams provides a simple and direct method, once the conversion is made to Federal Money, to convert within the regional currencies.

- $\quad$ To change the New-England to the New York currency ; add one third.

- $\quad$ To change the New York to the New-England currency ; subtract one fourth.

- $\quad$ To change the New-England to the Pennsylvania currency; add one fourth.

- $\quad$ To change the Pennsylvania to the New-England currency ; subtract one fifth.

- $\quad$ To change the New York to the Pennsylvania currency ; subtract one sixteenth.

- $\quad$ To change the to Pennsylvania the New York currency ; add one fifteenth.” (Adams, p.89.)

These rules utilize the relationship between the exchange rates and make conversion between the regional currencies easier once the conversion to Federal money has been made. The wording of these rules may seem a bit backward but consider this example taking the first rule: "To change the New-England to the New York currency ; add one third." The implication here is that New England currency is worth one third more than New York currency. In our example above, we converted New York currency of $£ 47$ 7s. 10 3/4 d. to Federal dollars and obtained $\$ 118.48$ and 7 mills. Increasing this by one-third yields $\$ 157.98$, the value of the same amount ( $£ 477 \mathrm{~s} .103 / 4 \mathrm{~d}$.) denominated in New England currency. 


\section{CONCLUSIONS}

Why was the European Union able to merge 12 disparate currencies more quickly than the experience of the United States in providing a single currency? When the European Union went to a single currency, they had two significant advantages.

- $\quad$ First, the concept and role of a central bank was well established and agreed by the participating states. Much of the delay in establishing a single currency in the United States arose from political viewpoints regarding central banking. Reportedly, many, including President Washington, were not sure the Constitution granted the central government the authority to establish a central bank. Alexander Hamilton, the first Secretary of the Treasury, was the initial driving force behind this concept. Ultimately, this political uncertainty led to Jackson's veto of the central bank in 1832 and the cessation of central banking operations from 1836, when the charter expired, until the Civil War in the 1860s. Ultimately, a true central bank, the Federal Reserve, was not established in the United States until 1913, nearly 140 years after the establishment of the nation. (U.S. Treasury Department 2005, Federal Reserve Bank of San Francisco 1995).

- Second, in the European Union, all of the component currencies were already denominated in decimals, making currency conversion an easier task. The last European holdout from the decimal system was England, which has not adopted the Euro. England converted to the decimal system in 1971. An argument could also be made here that the advance of technology also played a role. Clearly the laborious rules provided here to convert regional currencies to the "Federal Dollar" could easily be programmed into a spreadsheet currency converter. The problem would have remained, however, that trade between the regions would still have been unnecessarily complicated by the need for such currency exchange, exacerbated by the lack of a decimal currency base.

The historical actions taken in the formation of the United States cast a long shadow. In introducing the concept of a decimal currency in 1786, the United States set the stage for the easy conversion of disparate national currencies in world commerce in the twenty-first century.

\section{REFERENCES}

1. Adams, Daniel. The Scholar's Arithmetic; or, Federal Accountant. (10/e), New Hampshire: 1816.

2. Pickett, Joseph P. et al, eds. American Heritage Dictionary of the English Language. (4/e.) mill. Boston: Houghton Mifflin, 2000.

3. California, State of. Department of Pesticide Regulation website. Mill Assessment. (www.cdpr.ca.gov).

4. Economic Union. 2002. The European Union: A Guide for Americans. Washington DC. www.eurunion.org/infores/euguide/euguide.htm

5. $\quad$ Encyclopedia. com. Development of Modern Accounting. 2002. http://www.encyclopedia.com/html/section/accounti developmentofmodernaccounting.asp.

6. $\quad$ Fisher, George. The instructor, or, Young man's best companion. London: 1792.

7. Flsher, Dale L., Mranti, P., Previts, G. The First Century of the CPA. Journal of Accountancy. New York: October 1996, Vol. 182, Issue 4, pp.51-56.

8. Lee, Chauncey. American Accomptant, for the bookkeeper. 1797.

9. Nietz, John A. Old textbooks: spelling, grammar, reading, arithmetic, geography, American history, civil government, physiology, penmanship, art, music, as taught in the common schools from colonial days to 1900. Pittsburgh, University of Pittsburgh Press. 1961.

10. Nietz, John A. Full Text Searchable Collection of 140 old schoolbooks. http://digital.library.pitt.edu/cgibin/t/text/text-idx?c=nietz.

11. Pike, Nicholas. A New and Complete System of Arithmetic Composed for the use of the Citizens of the United States. 1792

12. $\quad$ Pike, Nicholas. System of arithmetick abridged Concord: Jacob. Moore. 1826.

13. United States Acts of Congress Chapter XII. An Act to establish the Treasury Department 1789.

14. United States, Federal Reserve Bank of San Francisco. A Brief History Of Money. 1995. http://www.frbsf.org/publications/federalreserve/annual/1995/history.html 
15. United States Metric Association. Conversion to Decimal Currency.

http://lamar.colostate.edu/ hillger/currency.htm. 2005

16. United States Treasury Department History of the Treasury. 2005. http://www.treas.gov/education/history/

17. Workman, Benjamin. American Accountant, or Schoolmaster's New Assistant

\section{ENDNOTE}

${ }^{111}$ California assesses a fee on all pesticide sales, levied at the point of first sale into the state. A "mill" is equal to onetenth of a cent. In 2004, this "mill assessment" was 21 mills, or 2.1 cents per dollar of sales. (www.cdpr.ca.gov) 